TELES, Tayson Ribeiro. Para que serve e/ou a quem serve uma Constituição? Jusfilosofias à luz de Sieyès, Lassalle, Hesse e Haberle. Revista Eletrônica Direito e Política, Programa de Pós-Graduação Stricto Sensu em Ciência Jurídica da UNIVALI, Itajaí, v.13, n.1, $1^{0}$ quadrimestre de 2018. Disponível em: www.univali.br/direitoepolitica - ISSN 1980-7791

\title{
PARA QUE SERVE E/OU A QUEM SERVE UMA CONSTITUIÇÃO? JUSFILOSOFIAS À LUZ DE SIEYĖS, LASSALLE, HESSE E HABERLE ${ }^{1}$
}

\author{
TO SERVE OR WHO SERVE (OR SHOULD SERVE) A CONSTITUTION? \\ REFLECTIONS ON SIEYĖS, LASSALLE, HESSE E HABERLE
}

Tayson Ribeiro Teles ${ }^{2}$

SUMÁRIO: Introdução; 1 . O que é o Direito?; 2. O que é uma Constituição?; 3. A quem deve servir uma Constituição? Reflexões em Sieyès; 4. Qual deve ser a essência de uma Constituição? Ponderações em Lassalle; 5. Deve-se ver uma Constituição como lei? Reflexões em Hesse; 6. Como interpretar uma Constituição? Ponderações em Haberle; Considerações Finais; Referências das Fontes Citadas.

\section{RESUMO}

No presente escrito, tem-se o escopo de tecer um plexo de reflexões sobre a função de uma Constituição, na perspectiva de pensar para que este gênero normativo deve existir, bem como a quem deve servir. A metodologia de feitura da pesquisa é a exploração bibliográfica revisional qualitativa e o caminho perquirido rumo ao alcance das reflexões lastreou-se na dedução, por meio da qual se parte de dados gerais e erigem-se ideias singulares. Para tal, faz-se uso dos pensamentos gerais de Sieyès, Lassalle, Hesse e Haberle, ideias tais presentes em suas mais importantes obras, e auferem-se reflexões particulares - a investigação em si. Os resultados demonstram, em escorço, que uma Constituição serve para fundar uma nação, garantindo direitos fundamentais a seu povo, e servir-lhe de baliza para a confecção de outras normas, além do que a Constituição deveria servir ao povo, a todos (hipótese), mas infelizmente serve em maior grau a poucos, notadamente os donos do capital/poder.

PALAVRAS-CHAVE: Constituição; Sieyès; Lassalle; Hesse; Haberle.

\section{ABSTRACT}

In this essay we have the scope to weave a plexus of reflections on the role of a Constitution with a view to think that this normative gender should be and who should serve. The making of research methodology is qualitative review literature

${ }^{1} \mathrm{O}$ presente artigo foi publicado em Anais do X Simpósio Linguagens e Identidades da/na Amazônia Sul-Ocidental,

(2016)

(http://revistas.ufac.br/revista/index.php/simposioufac/issue/view/48/showToc)

2 Mestre em Letras: Linguagem e Identidade (Cultura e Sociedade) pela Universidade Federal do Acre - UFAC (2016) e Bacharel em Direito (2017) pela mesma instituição. Aprovado na OAB (2016). Possui 4 Especializações: Gestão de Políticas Públicas, pela Universidade Federal de Ouro Preto/MG (2016); Gestão da Educação Científica, pelo IFAC/AC (2015); Tecnologias da Informação e Comunicação, pela UFAC/AC (2015); e Gestão Administrativa na Educação, pela ESAB/ES (2014). Licenciado em Matemática pelo Centro Claretiano, de Batatais/SP (2016). Graduado em Tecnologia em Gestão Financeira (Finanças), pelo Centro UniSEB/Estácio, de Ribeirão Preto-SP (2013). Servidor Público Federal. Email: tayson.rteles@gmail.com 
TELES, Tayson Ribeiro. Para que serve e/ou a quem serve uma Constituição? Jusfilosofias à luz de Sieyès, Lassalle, Hesse e Haberle. Revista Eletrônica Direito e Política, Programa de Pós-Graduação Stricto Sensu em Ciência Jurídica da UNIVALI, Itajaí, v.13, n.1, $1^{0}$ quadrimestre de 2018. Disponível em: www.univali.br/direitoepolitica - ISSN 1980-7791

exploration and done way towards achieving the reflections he walked on deduction, through which part of general data and erect up unique ideas. To do this, we use the private thoughts of Sieyes, Lassalle, Hesse and Haberle, these gift ideas in their most important works. The results show that, in foreshortening, a Constitution serves to found a nation, guaranteeing fundamental rights to its people, and serve him beacon for making other standards beyond what the Constitution should serve the people, all but unfortunately serves a greater degree a few, especially the owners of capital/power.

KEYWORDS: Constitution; Sieyès; Lassalle; Hesse; Haberle

\section{INTRODUÇÃO}

Neste artigo, intenta-se o engendro de reflexões sobre o instituto jurídico da Constituição, notadamente o mais importante e imponente diploma legal de qualquer democracia, o qual serve de viga mestra, norma originária e baliza legal precípua para as demais regras erigidas nas comunidades. O problema de pesquisa se resume à seguinte indagação: para que serve e/ou a quem serve uma Constituição?

Em sede de revisão bibliográfica exploratória qualitativa, ou seja, estudo por meio da compulsão de livros e suas qualidades teóricas, lastreia-se as ponderações, reflexões, inferências e pensamentos no caminho de ideias de quatro autores primordiais para o Direito Constitucional hodierno, a saber: Sieyès, Lassalle, Hesse e Haberle.

Ao unir-se sistematicamente os teoremas desses quatro renomados juristas de séculos pretéritos, torna-se claro que uma Constituição deveria servir para fundar uma nação e garantir direitos fundamentais a seu povo - isto é a hipótese para o problema de pesquisa. De revés, porém, obstante a isso, infelizmente, a maioria das Constituições contemporâneas servem em maior grau a poucos, notadamente os donos do capital/poder - os políticos e os empresários.

O texto subdivide-se em seis seções e considerações finais. Inicialmente abordase um conceito de Direito, a Ciência Jurídica, com foco crítico às relações de poder estatuídas nas sociedades modernas, onde vicejam ideologias, exploração, capitalismo, (neo)liberalismo e outros eventos sociais. Após, tece-se comentários sobre um conceito de Constituição. Ao seguinte, destina-se uma seção para cada um dos autores utilizados como teóricos na/da análise. Ao final, produz-se comentários finalizadores, quando se retoma a hipótese. 
TELES, Tayson Ribeiro. Para que serve e/ou a quem serve uma Constituição? Jusfilosofias à luz de Sieyès, Lassalle, Hesse e Haberle. Revista Eletrônica Direito e Política, Programa de Pós-Graduação Stricto Sensu em Ciência Jurídica da UNIVALI, Itajaí, v.13, n.1, 10 quadrimestre de 2018. Disponível em: www.univali.br/direitoepolitica - ISSN 1980-7791

\section{O QUE É O DIREITO?}

Antes de trazer-se à cena o mérito deste artigo, é cabível, para clarificar o tema e perfectibilizar compreensão ao leitor não familiarizado com o assunto/Direito, fazer-se breves comentários sobre o que venha a ser a Ciência Jurídica. Consubstanciou o professor Miguel Reale, em seu clássico Lições Preliminares de Direito, que na conceituação do que seja o Direito:

(...) o caminho mais aconselhável seja aceitar, a título provisório, ou para princípio de conversa, uma noção corrente consagrada pelo uso. Ora, aos olhos do homem comum o Direito é a lei e a ordem, isto é, um conjunto de regras obrigatórias que garantem a convivência social graças ao estabelecimento de limites à ação de cada um de seus membros. Assim sendo, quem age de conformidade com essas regras comporta-se direito, quem não o faz, age torto. ${ }^{3}$

Ora, esse parece um bom conceito do que seja o Direito. A didaticidade de Reale oferece uma ideia genérica do que seja o Direito. Porém, será que Direito é apenas isso - um conjunto de regras sociais -? Assevera Reale que esta pergunta não costumava ser feita antigamente, até o final do século XVIII. Isso, pois "(...) durante milénios o homem viveu ou cumpriu o Direito, sem se propor o problema de seu significado lógico ou moral" ${ }^{\prime 4}$. Diz o autor que apenas do início do século XIX para cá é que a civilização passou a perceber que o Direito se estrutura em valores e princípios independentemente das normas religiosas ou costumeiras e, por isso, somente desde então as pessoas têm dedicado um estudo mais aprofundado sobre esta Ciência.

Nesse rumo, em tentativa de resposta à pergunta sobre o que seja o Direito, é prudente crer que, dada à pluriversalidade de erros, infrações, crimes e contravenções que as pessoas cometem diariamente, a vida humana se resume a uma coisa: conflitos. O ser humano a todo o momento está em lides com seu semelhante e/ou com o Estado. A vida é um complexo de consentimentos e resistências. Ora aceita-se, ora reivindica-se. Todas as pessoas já tiveram algum

\footnotetext{
${ }^{3}$ REALE, Miguel. Noções preliminares de Direito. 25. ed. São Paulo: Saraiva, 2001, p. 1.

${ }^{4}$ REALE, Miguel. Noções preliminares de Direito, p. 2.
} 
TELES, Tayson Ribeiro. Para que serve e/ou a quem serve uma Constituição? Jusfilosofias à luz de Sieyès, Lassalle, Hesse e Haberle. Revista Eletrônica Direito e Política, Programa de Pós-Graduação Stricto Sensu em Ciência Jurídica da UNIVALI, Itajaí, v.13, n.1, 10 quadrimestre de 2018. Disponível em: www.univali.br/direitoepolitica - ISSN 1980-7791

tipo de desentendimento, não necessariamente judicial, com alguém - nem que seja consigo mesmas.

Com efeito, é, então, o Direito exatamente o conjunto desses conflitos, dessas relações humanas. Como afirmou-se que a vida se resume a conflitos, pensa-se, por via de consequência, que o Direito é em si mesmo a própria vida. Como? O Direito é superior a tudo? Não, todas as profissões e Ciências têm suas importâncias. Ocorre que por haver relação humana, perfectibilizada sempre pela linguagem, em tudo, e como em toda relação humana há conflitos, é plausível aceitar que toda a vida se resume a conflitos, portanto a Direito.

Tudo o que existe no universo diferente da natureza foi construído pelo homem, que o fez sempre mergulhado em conflitos, notadamente econômicos e religiosos (de classes). Assim, o Direito sim pode ser concebido como as várias coisas que é: uma faculdade (no sentido subjetivo de exercer-se Direitos que se tem apenas se se quiser), uma Ciência, um conjunto de normas, coisas assim. Contudo, além disso, é o Direito a própria vida. Para Miguel Reale, a experiência jurídica somente pode ocorrer na relação diária do homem com seu semelhante ${ }^{5}$. É na sociedade e pela sociedade (a vida como um todo) que surge o Direito. Como narra o famoso brocardo romano ubi societas, ibi jus - onde há sociedade, há o Direito, e viceversa. Diz-se sociedade num sentido de "civilização"6, mas não para menosprezar grupos que vivem de formas diferentes da do homem urbano.

Refere-se à sociedade, pois é nela - nesse grupo urbano, globalizado, híbrido e cambiante - onde vivem todos. Há outros grupos sociais, indígenas, por exemplo, que têm seus próprios modos de vida, seus "direitos" e vivem muito bem com eles. Todavia, a humanidade deve se incomodar apenas com sua sociedade e seus problemas, parando de querer impor seu modus vivendi para o Outro, como fizeram os europeus quando aqui chegaram. Não se pode, no exemplo citado, querer ensinar aos indígenas como viver, se vestir etc. Eles sobrevivem nos rincões

\footnotetext{
${ }^{5}$ Aqui deve-se por em observação este vocábulo, a fim de se entender a escusa afirmação burguesa de que todos são "iguais perante a lei". Podemos ser semelhantes em algumas coisas, ser de mesmas classes, gostar de mesmas comidas etc., mas somos todos diferentes e únicos, inclusive os gêmeos univitelínicos, e precisa-se ressaltar isso sempre.

${ }^{6}$ Um discurso sobre o que seria um modo padrão de vida.
} 
TELES, Tayson Ribeiro. Para que serve e/ou a quem serve uma Constituição? Jusfilosofias à luz de Sieyès, Lassalle, Hesse e Haberle. Revista Eletrônica Direito e Política, Programa de Pós-Graduação Stricto Sensu em Ciência Jurídica da UNIVALI, Itajaí, v.13, n.1, 10 quadrimestre de 2018. Disponível em: www.univali.br/direitoepolitica - ISSN 1980-7791

do Brasil sendo humilhados há mais de 500 anos e vivem de uma forma muito agradável e feliz, em comunhão com a natureza.

Mas, sendo o Direito a própria vida, então, como deve ser esta vida? Como as vidas humanas devem ou deveriam funcionar? Bem:

(...) como notava o grande líder marxista italiano Gramsci, a visão dialética precisa alargar o foco do Direito, abrangendo as pressões coletivas e até [...] as normas não-estatais de classe e grupos espoliados e oprimidos que emergem da sociedade civil e adotam posições vanguardeiras, como sindicatos, partidos, setores de igrejas, associações profissionais e culturais e outros veículos de engajamento progressista. O Direito autêntico e global não pode ser isolado em campos de concentração legislativa, pois indica os princípios e normas libertadoras, considerando a lei um simples acidente no processo jurídico e que pode, ou não, transportar as melhores conquistas. ${ }^{7}$

O Direito como vida deve abarcar, proteger e tutelar todos os setores da sociedade/vida? É isso, é bem simples a questão? Deveria ser. Entretanto, o Direito não é assim e a razão disso é a dupla dinheiro/poder. O grande problema que exsurge é a constatação de que no Direito:

A lei sempre emana do Estado e permanece, em última análise, ligada à classe dominante, pois o Estado, como sistema de órgãos que regem a sociedade politicamente organizada, fica sob o controle daqueles que comandam o processo econômico, na qualidade de proprietários dos meios de produção. ${ }^{8}$

Mas, sempre a lei é ruim para os pobres e beneficia apenas os detentores do capital/poder? Não, na verdade, "a legislação abrange sempre Direito e Antidireito: isto é, Direito propriamente dito, reto e correto, e negação do Direito, entortado pelos interesses classísticos e caprichosos continuístas do poder estabelecido" ${ }^{\prime \prime}$. Noutro modo de explanar: os poderosos fazem leis que ora beneficiam os pobres, ora os ricos. É como se pensassem, grosso modo: "vamos dar uns direitozinhos

\footnotetext{
7 LYRA, Roberto Filho. 0 que é Direito. São Paulo: Brasiliense, 2012, p. 10.

8 LYRA, Roberto Filho. O que é Direito, p. 8.

${ }^{9}$ LYRA, Roberto Filho. O que é Direito, p. 8.
} 
TELES, Tayson Ribeiro. Para que serve e/ou a quem serve uma Constituição? Jusfilosofias à luz de Sieyès, Lassalle, Hesse e Haberle. Revista Eletrônica Direito e Política, Programa de Pós-Graduaç̧ão Stricto Sensu em Ciência Jurídica da UNIVALI, Itajaí, v.13, n.1, $1^{\circ}$ quadrimestre de 2018. Disponível em: www.univali.br/direitoepolitica - ISSN 1980-7791

para eles se entreterem um pouco". Isso, pois notadamente os melhores e maiores Direitos são dos e para os donos do capital.

\section{QUE É UMA CONSTITUIÇÃO?}

Várias são as perspectivas sobre o conceito de Constituição. Disse Ulysses Guimarães - o promulgador da Constituição da República Federativa do Brasil de 1988 (CRFB/88), em setembro de 1988, na sessão de aprovação final do texto de da atual Constituição pátria, conhecida por "Constituição Cidadã", que "a Constituição é uma carta de compromissos assumidos livremente pelos cidadãos, em determinado tempo e sociedade"10. Será que é livremente mesmo ou tal norma é, na verdade, um conjunto de regras impostas por certa parcela de cada sociedade, notadamente suas elites?

Todos têm uma mínima e vaga noção do que seja tal documento enquanto instituto jurídico supremo de uma nação. Qualquer de nós já verbalizou célebres construções vocabulares como "isso é meu direito, pois está na Constituição" ou "não tem educação, saúde, segurança, estão violando a Constituição". Verdadeiramente, todos têm uma ideia comum do que seja a Constituição de um país. Porém, tecnicamente, o que é uma Constituição? Qual a origem deste instrumento jurídico? Para que serve e/ou a quem serve?

Esclarece-nos Rodrigo César Rebello Pinho que a primeira ideia de Constituição surgiu por volta de 1215 na Inglaterra, quando objetivando limitar o poder do Estado monarca, foi firmada uma Magna Carta entre o Rei João Sem Terra, o Papa da época e os Barões. O acordo foi levado a efeito, visto que havia muitas disputas e desinteligências sobre os poderes absolutos de que dispunha o soberano. Estampava o documento que o Rei João não teria poderes absolutos, deveria se sujeitar a alguns procedimentos e teria de reconhecer que sua vontade sempre estaria sujeita às permissões da lei.

Diz o pesquisador que depois aconteceram outros fatos que colaboraram para o surgimento e solidificação da ideia de necessidade de um documento que limitasse os poderes dos governantes. Houve, em 1628, a Petition of Rigluts, uma

\footnotetext{
${ }^{10}$ GUTEMBERG, Luiz. Ulysses Guimarães. 2. ed. Brasília: Câmara dos Deputados, 2012, p. 408.
} 
TELES, Tayson Ribeiro. Para que serve e/ou a quem serve uma Constituição? Jusfilosofias à luz de Sieyès, Lassalle, Hesse e Haberle. Revista Eletrônica Direito e Política, Programa de Pós-Graduação Stricto Sensu em Ciência Jurídica da UNIVALI, Itajaí, v.13, n.1, 10 quadrimestre de 2018. Disponível em: www.univali.br/direitoepolitica - ISSN 1980-7791

petição/documento firmada(o) entre o Rei inglês Carlos I e seus súditos, por meio da(o) qual aquele soberano abriu mão de alguns poderes, dentre outros acontecimentos históricos.

Contudo, evidencia o autor que:

As primeiras Constituições propriamente ditas surgiram em decorrência das grandes revoluções democrático-burguesas do final do século XVIII, a Revolução Americana de 1776, com a independência das treze colônias britânicas situadas na América do Norte, e a Revolução Francesa de 1789, que pôs fim ao Ancién Régime. A primeira Constituição escrita foi a do Estado da Virgínia, em 1776, elaborada meses antes da declaração de independência americana. Em seguida, foram proclamadas as dos Estados Unidos da América, em 1787, e a francesa de 1791 . Após o advento daquelas revoluções, com a consequente promulgação dessas Constituições, o constitucionalismo, como movimento revolucionário de tendência universal, alcançou os demais países, inclusive o Brasil. É indispensável frisar que ele, como movimento político, estava intimamente relacionado com os valores do liberalismo político, de limitação do poder governante e de valorização dos direitos do indivíduo. A Declaração dos Direitos do Homem e do Cidadão, proclamada após a Revolução Francesa, em 1789, dispunha que o país que não estabelecesse uma separação de poderes, nem uma declaração de direitos individuais, não possuiria uma Constituição. ${ }^{11}$

Nesse tonário, o escorço que se pode fazer remete ao fato de que, em essência, a Constituição surgiu como uma vontade da burguesia, à época "pobre" e hoje rica, de gozar dos mesmos direitos dos nobres (realezas) e dos clérigos (membros da Igreja Católica). Tal vontade foi muito bem revelada nos ideais da Revolução Francesa: Liberté, Egalité, Fraternité (liberdade, igualdade e fraternidade). A burguesia pregava querer a igualdade entre todos. O problema é que essa burguesia quando chegou ao poder verificou o quão bom eram os privilégios dos que lá estavam, os nobres, olhou para trás, viu o povo, a massa, os trabalhadores, os esfomeados, os doentes e, em espasmo psicológico, percebeu que não havia

11 PINHO, Rodrigo César Rebello. Teoria geral da Constituição e direitos fundamentais. 11. ed. São Paulo: Editora Saraiva, 2011, p. 26. 
TELES, Tayson Ribeiro. Para que serve e/ou a quem serve uma Constituição? Jusfilosofias à luz de Sieyès, Lassalle, Hesse e Haberle. Revista Eletrônica Direito e Política, Programa de Pós-Graduação Stricto Sensu em Ciência Jurídica da UNIVALI, Itajaí, v.13, n.1, 10 quadrimestre de 2018. Disponível em: www.univali.br/direitoepolitica - ISSN 1980-7791

espaço para que todos gozassem das benesses do Estado - não seria possível uma igualdade material, os recursos eram poucos.

Logo, abrupta e rapidamente, os pequenos burgueses transfiguraram seus ideais, ideologicamente, e passaram a dizer que a igualdade não seria possível material e imediatamente, sendo um objetivo a ser conquistado progressivamente. Assim, quanto a este princípio da igualdade, que:

(...) no Brasil está no Art. $5^{\circ}$ da Constituição da República Federativa do Brasil de 1988 (CRFB/88) e por isso é chamado de Princípio Constitucional da Igualdade, Mello (2003) diz que a atual noção de igualdade presente no Brasil, deriva das revoluções burguesas dos séculos XVIII e XIX. Tais sublevações institucionalizaram o postulado do igualitarismo, proveniente da ética cristã, segundo o qual todos os seres humanos, somente por serem dotados de humanidade, são possuidores do mesmo quantum de dignidade. Nessa fase, o direito à igualdade surgiu como oposição aos privilégios reais absolutistas, ocasião em que a burguesia reivindicou a vez à igual dignidade de que gozavam os clérigos, os reis, os políticos etc. As pressões dessas revoluções impuseram ao Estado o dever de editar regras gerais e impessoais, não individualizadas ou específicas, a fim de distribuírem-se os bens e as vantagens da sociedade de forma equânime, com base nas potencialidades humanas e não em privilégios de classe. $^{12}$

Falou-se rapidamente sobre a origem da Constituição, mas hoje em dia o que ela é? Bem, pode-se dizer que:

(...) a Constituição de uma nação é um sistema normativo aberto formado por dois tipos de normas, os princípios e as regras, ambos espécies do gênero norma constitucional, revestidos da mesma dignidade e da mesma força de lei e de direito positivo, porém, com diferentes formas de concretização. ${ }^{13}$

12 TELES, Tayson Ribeiro. Política de Cotas do Ensino Superior Brasileiro: Uma análise percuciente in faciem do Princípio Constitucional da Igualdade. Constituição, Economia e Desenvolvimento: Revista da Academia Brasileira de Direito Constitucional, Curitiba, v. 7, n. 12, jan-jun, 2015, p. 237-238.

13 TELES, Tayson Ribeiro. Política de Cotas do Ensino Superior Brasileiro: Uma análise percuciente in faciem do Princípio Constitucional da Igualdade. Constituição, Economia e Desenvolvimento: Revista da Academia Brasileira de Direito Constitucional, p. 238. 
TELES, Tayson Ribeiro. Para que serve e/ou a quem serve uma Constituição? Jusfilosofias à luz de Sieyès, Lassalle, Hesse e Haberle. Revista Eletrônica Direito e Política, Programa de Pós-Graduação Stricto Sensu em Ciência Jurídica da UNIVALI, Itajaí, v.13, n.1, 10 quadrimestre de 2018. Disponível em: www.univali.br/direitoepolitica - ISSN 1980-7791

Este conceito, do qual exalam lições de José Gomes Canotilho, é uma boa definição do que seja uma Constituição, porquanto a Constituição, apesar de ser uma norma, e que, portanto, deve ser cumprida, é, em verdade, um sistema aberto e subjetivo, na medida em que como é geralmente feita para perdurar por muito tempo, aqui e acolá sofre modificações a fim de acompanhar a evolução da sociedade, a mudança de costumes etc.

Dessa forma, em uma Constituição não há apenas mandamentos fixos, há também princípios com ampliada possibilidade de interpretação. Por exemplo, na CRFB/88 há o axioma da dignidade da pessoa humana, mas o que é isso? O que é digno para o ser humano? Várias podem ser as coisas que tornam uma pessoa digna ou oferecem a ela condições de ter uma vida digna, não há como se elencar pressupostos taxativos que limitem este princípio. Assim, apesar de aberto ele é uma norma e cabe ao Estado oferecer dignidade a todos, na medida da necessidade individual de cada um.

Este conceito trazido à baila não é absoluto. Apenas é o em que se baseia o sistema constitucional brasileiro. Existem várias formas, tipos e classificações de Constituição, como: Constituição Sociológica, Política, Material, Formal, Jurídica, Nacional, Escrita, Real, Não-escrita, Costumeira, Fechada, Aberta, Culturalista, Dogmática, Histórica, Liberal/negativa, Social/positiva, Rígida, Semirrígida, Flexível, Promulgada, Outorgada, Cesarista, Pactuada, Democrática, Popular, Principiológica, Preceitual, Garantista, Programática, Analítica, Semântica etc. ${ }^{14}$

À evidência, para não se correr do tema da investigação proposta, não é necessário que se comente cada um desses tipos constitucionais. Como diz Rodrigo César Rebello Pinho, o importante é saber que uma Constituição deve possuir os seguintes elementos: forma de governo (Monarquia ou República); sistema de governo (Parlamentarista ou Presidencialista); modo de aquisição, exercício e perda do poder político; órgãos de atuação do Estado (Executivo, Legislativo e

\footnotetext{
14 A CRFB/88 é classificada como formal, escrita, dogmática, social, rígida (ou super rígida), democrática, dirigente, programática, principiológica, analítica, eclética, normativa, originária, plástica e expansiva.
} 
TELES, Tayson Ribeiro. Para que serve e/ou a quem serve uma Constituição? Jusfilosofias à luz de Sieyès, Lassalle, Hesse e Haberle. Revista Eletrônica Direito e Política, Programa de Pós-Graduação Stricto Sensu em Ciência Jurídica da UNIVALI, Itajaí, v.13, n.1, $1^{0}$ quadrimestre de 2018. Disponível em: www.univali.br/direitoepolitica - ISSN 1980-7791

Judiciário); principais postulados da ordem econômica e social; e limites à atuação do Estado (direitos fundamentais da pessoa humana).

Nessa perspectiva, para compreensão de tais elementos, no mundo dos estudos jurídicos existem quatro obras basilares: "A Constituinte Burguesa", de Emmanuel Joseph Sieyès ${ }^{15}$; "A Essência da Constituição", de Ferdinand de Lassalle ${ }^{16}$; "A Força Normativa da Constituição", de Konrad Hesse17; e "Hermenêutica Constitucional: a sociedade aberta dos intérpretes da Constituição", de Peter Haberle ${ }^{18}$, obras estas sobre as quais se tecerá ponderações e reflexões a partir de agora.

\section{A QUEM DEVE SERVIR UMA CONSTITUIÇÃO? REFLEXÕES EM SIEYÈS}

Em "A Constituinte Burguesa", Sieyès aduziu, se referindo ao povo mais pobre da França do século XVIII, à época chamado de o Terceiro Estado (os outros dois Estados eram integrados um pelo clero e a nobreza e o outro pelos ricos, os donos dos meios de produção), que "o Terceiro Estado abrange, pois, tudo o que pertence

15 Político e escritor francês que viveu entre 1748 e 1836 . Foi contemporâneo de Napoleão Bonaparte, com quem atuou como Cônsul. Teve participação do Golpe do 18 Brumário. Era rico, foi um dos representantes nos Estados Gerais franceses da Igreja e da aristocracia. Contudo, sempre teve pensamentos voltados para o povo. Nesta obra "A Constituinte Burguesa", publicada às vésperas da Revolução Francesa, baseado na fictícia Teoria do Contrato Social, surge com a ideia de poder existir um Poder superior aos poderes instituídos, um poder que fosse imanente à nação, o que chamou de Poder Constituinte. Esta obra basicamente visava a conformar a ascensão do Terceiro Estado (o povo) ao poder político.

16 Polonês que viveu entre 1825 e 1864 e foi um dos precursores da social democracia alemã. Foi contemporâneo de Karl Marx e em 16 de abril de 1862 proferiu em uma associação liberalprogressista de Berlim um discurso que posteriormente serviu de base para este livro "A Essência da Constituição". Nesta obra, basicamente, Lassalle cunhou a concepção sociológica da Constituição, dizendo que esta deve sempre descrever exatamente a realidade social e política das nações, caso contrário, tal documento torna-se apenas uma "folha de papel". Disse ele que a Constituição deve conter todos os "fatores reais de poder".

17 Jurista alemão que viveu entre 1919 e 2005, tendo sido juiz do Tribunal Federal Constitucional Alemão, órgão análogo ao Supremo Tribunal Federal (STF) brasileiro, entre 1975 e 1987. Nesta obra "A Força Normativa da Constituição", basicamente, diz que a Constituição não pode apenas, como quis Lassalle, descrever a realidade de uma nação, pois caso faça isso servirá somente como um documento sociológico. Para ele, a Constituição deve ser um documento com força de lei. Essa sua ideia ganhou o nome de concepção concretista da Constituição.

18 É um jurista alemão ainda vivo, nascido em 1934. Fez Doutorado em Direito na Universidade de Freiburg, onde foi orientado pelo sobredito Konrad Hesse. Nesta obra "Hermenêutica Constitucional: a sociedade aberta dos intérpretes da Constituição", basicamente, prega que a Constituição de uma nação não deve ser interpretada apenas pelas autoridades, mas também por qualquer cidadão ou grupo social. 
TELES, Tayson Ribeiro. Para que serve e/ou a quem serve uma Constituição? Jusfilosofias à luz de Sieyès, Lassalle, Hesse e Haberle. Revista Eletrônica Direito e Política, Programa de Pós-Graduação Stricto Sensu em Ciência Jurídica da UNIVALI, Itajaí, v.13, n.1, 10 quadrimestre de 2018. Disponível em: www.univali.br/direitoepolitica - ISSN 1980-7791

à nação. E tudo o que não é Terceiro Estado não pode ser olhado como pertencente à nação. Quem é o Terceiro Estado? Tudo"19.

Veja-se o que disse este revolucionário ainda no século XVIII. Para ele em uma nação o povo mais pobre é, ou deve ser, tudo. Que força tem essa ideia? Pode-se pensar que no Brasil de hoje o povo mais pobre é tudo? Uma mãe e um pai sempre costumam dizer que seus filhos são tudo para eles e que por eles fazem/fariam qualquer coisa - tudo. Será que se as autoridades pátrias vissem os mais pobres como tudo, fariam tudo por eles? Por que os veem como tudo apenas em certos primeiros domingos de outubro a cada quatro anos?

Sieyès asseverou, na iminência da Revolução Francesa: "(...) resumindo, o Terceiro Estado não teve, até agora, verdadeiros representantes nos Estados Gerais [órgão análogo ao atual Congresso Nacional brasileiro, o parlamento]. Desse modo, seus direitos políticos são nulos"20. Pergunta-se: será que no Brasil os pobres tiveram até hoje verdadeiros representantes no parlamento? Fala-se dos pobres mesmo, os paupérrimos? Parece difícil, pois como sem dinheiro conseguiriam eleger representantes, não é verdade?

Sieyès exclamou que "(...) os defensores da aristocracia (...), os homens que nascidos com muito espírito e pouca alma, são (...) ávidos de poder, e dos afagos dos grandes $(\ldots)^{\prime 21}$. Isso lembra alguma coisa? Como se comporta a maioria dos políticos brasileiros? O que provam as delações da Odebrecht e da JBS, bem como a Operação Lava Jato e seus deslindes?

Disse ainda este inquieto francês que:

Além do império da Aristocracia que, na França, dispõe de tudo, e desta superstição feudal que avilta ainda a maior parte dos espíritos (refere-se ao contexto de sua época na França], existe a influência da propriedade: está é natural, não a condeno. Mas, é preciso convir que ela não deve ser uma vantagem dos privilegiados e, por isto, podemos temer, com

19 SIEYĖS, Joseph Emmanuel. A constituinte burguesa. Tradução de Norma Azevedo. 5. ed. Rio de Janeiro: Editora Lúmen Juris, 2009, p. 5.

20 SIEYÈS, Joseph Emmanuel. A constituinte burguesa, p. 13.

21 SIEYÈS, Joseph Emmanuel. A constituinte burguesa, p. 17. 
TELES, Tayson Ribeiro. Para que serve e/ou a quem serve uma Constituição? Jusfilosofias à luz de Sieyès, Lassalle, Hesse e Haberle. Revista Eletrônica Direito e Política, Programa de Pós-Graduação Stricto Sensu em Ciência Jurídica da UNIVALI, Itajaí, v.13, n.1, 10 quadrimestre de 2018. Disponível em: www.univali.br/direitoepolitica - ISSN 1980-7791

razão, que ela Ihes dê seu poderoso apoio contra o Terceiro Estado. ${ }^{22}$

Perlustre-se com acuidade o que reverberou este homem há mais de duzentos anos. Para ele a propriedade privada não deve ser condenada, pois cada pessoa de fato tem o direito de ter um local, uma casa para morar. O buscável é que a propriedade não seja um privilégio dos que têm mais dinheiro ou poder. Nesse ponto, parece interessante pensar se é mesmo aceitável que no atual Brasil exista tanta gente sem um casebre ${ }^{23}$ para viver e pouca gente com enormes quantitativos de hectares de terras em seu nome?

Para Sieyès, quanto ao Terceiro Estado, seria interessante "que seus deputados sejam em número igual ao da nobreza e do clero"24. Seria possível isso no Brasil? Seria interessante que houvesse uma norma limitando o quantum de parlamentares ricos possível de ser eleito? Mas, será que não haveria artimanhas dos abastados que usariam "laranjas" como proprietários oficiais de seus bens, apenas para ingressarem no poder, e/ou nele se manterem, vestidos com falso véu da pobreza?

Outrossim, obtemperou Sieyès que:

A Constituição não é obra do poder constituído, mas do poder constituinte. Nenhuma espécie de poder delegado pode mudar nada nas condições de sua delegação. É neste sentido que as leis constitucionais são fundamentais. As primeiras, as que estabelecem a legislatura, são fundadas pela vontade nacional antes de qualquer constituição; formam seu primeiro grau. As segundas devem ser estabelecidas por uma vontade representativa especial. Desse modo, todas as partes do governo dependem em última análise da nação. Estamos dando somente uma vaga ideia, mas ela é exata. ${ }^{25}$

\footnotetext{
22 SIEYÈS, Joseph Emmanuel. A constituinte burguesa, p. 17.

23 Não usa-se este termo em tom de menosprezo por pequenas habitações. Apenas tenta-se, por meio dele, expressar/representar um mínimo habitável, ao qual muita gente não tem acesso, ou porque mora na rua ou alugado.
}

24 SIEYÈS, Joseph Emmanuel. A constituinte burguesa, p. 24.

25 SIEYÈS, Joseph Emmanuel. A constituinte burguesa, p. 55. 
TELES, Tayson Ribeiro. Para que serve e/ou a quem serve uma Constituição? Jusfilosofias à luz de Sieyès, Lassalle, Hesse e Haberle. Revista Eletrônica Direito e Política, Programa de Pós-Graduação Stricto Sensu em Ciência Jurídica da UNIVALI, Itajaí, v.13, n.1, 10 quadrimestre de 2018. Disponível em: www.univali.br/direitoepolitica - ISSN 1980-7791

O que o autor quis externar? Afirmou que deve haver um poder primeiro que faça a Constituição de uma nação e este poder deve servir exclusivamente para isso, não podendo seus integrantes permanecerem com mandatos após a feitura da norma. Em seguida, devem ser eleitos membros para o parlamento e estes não podem ter o poder de modificar a Constituição, apenas podendo fazer leis especiais. Isso seria praticável no Brasil? Seria aplicável procedimento assim nesta nação que desde 1988 já modificou, por meio de Emendas Constitucionais (EC), sua Constituição mais de noventa vezes?

Propalou, também, Sieyès que:

Em toda nação livre - e toda nação deve ser livre - só há uma forma de acabar com as diferenças, que se reproduzem com respeito à Constituição. Não é aos notáveis que se deve recorrer, é à própria nação. Se precisamos de Constituição, devemos fazê-la. Só a nação tem direito de fazê-la. Se temos uma Constituição, como alguns se obstinam em afirmar, e que por ela a assembleia geral é dividida, de acordo com o que pretendem, em três câmaras de três ordens de cidadãos, não podemos, por isso deixar de ver que existe da parte de uma dessas ordens uma reclamação tão forte, que é impossível avançar sem julgá-la. ${ }^{26}$

Indaga-se: disse Sieyès que a Constituição deve ser produzida pela nação, pelo povo, pelo Terceiro Estado. No case brasileiro, a CRFB/88 foi feita por quem? Quem eram os constituintes? Eram pobres? Eram ricos em sua maioria! Sieyès pregava a união do povo francês de sua época, em meio ao estopim da Revolução. Analisando sua pregação, pensa-se: será que a maioria (metade mais um) sempre representará a opinião de todos? Sieyès inquiriu e respondeu: "O que é a vontade de uma nação? É o resultado de vontades individuais, como a nação é a reunião de indivíduos"27. Veja-se a força desta colocação. Ora, Sieyès nos faz pensar que a maioria não é verdadeiramente a vontade de todos, mas apenas a soma de vontades individuais, de pessoas únicas e irrepetíveis.

\footnotetext{
${ }^{26}$ SIEYÈS, Joseph Emmanuel. A constituinte burguesa, p. 51.

27 SIEYÈS, Joseph Emmanuel. A constituinte burguesa, p. 79.
} 
TELES, Tayson Ribeiro. Para que serve e/ou a quem serve uma Constituição? Jusfilosofias à luz de Sieyès, Lassalle, Hesse e Haberle. Revista Eletrônica Direito e Política, Programa de Pós-Graduação Stricto Sensu em Ciência Jurídica da UNIVALI, Itajaí, v.13, n.1, 10 quadrimestre de 2018. Disponível em: www.univali.br/direitoepolitica - ISSN 1980-7791

Sieyès exarou ser "[...] impossível conceber uma associação legítima que não tenha como objeto a segurança comum, a liberdade comum, enfim, a coisa pública"28. Cabe indagar: a associação de pessoas que fizeram a CRFB/88 a fez pensando no bem comum? E mais: aquela associação - a Assembleia Nacional Constituinte (ANC) de 1987-88, foi uma comissão legítima no sentido de verdadeiramente representar, quer dizer presentar (ser de fato), o povo?

Em sua obra Sieyès faz sugestões sobre como acreditava que deveria funcionar o Estado Francês do século XVIII. São curiosas as ideias deste revolucionário. Quando nota-se que ele era um aristocrata, rico e abastado político e, mesmo assim, teve ideias tão direcionadas ao povo, pensa-se ser factível ainda crer-se que existe(a)m, ou podem existir, homens públicos que pensem de facto no bem comum.

Sieyès consubstanciou que:

Conhecemos o verdadeiro objetivo de uma assembleia nacional: não é feita para se ocupar dos assuntos particulares dos cidadãos. Ela considera-os como uma massa (...). Tiremos a consequência natural: que o direito de fazer-se representar só pertence aos cidadãos por causa das qualidades que thes são comuns e não devido àquelas que os diferenciam. As vantagens pelas quais os cidadãos diferem estão além do caráter do cidadão. As desigualdades de propriedade e de indústria são como as desigualdades de idade, de sexo, de tamanho etc. Não desnaturam a igualdade cívica. (...) essas vantagens particulares estão sob a salvaguarda da lei; (...) cabe ao legislador criar vantagens desta natureza, dar privilégios a alguns e negá-los a outros. A lei não concebe nada; protege o que existe até o momento em que o que existe começa a prejudicar o interesse comum. (...); todos os cidadãos, sem exceção, estão à mesma distância (...) e ocupam nela lugares diferentes; todos dependem igualmente da $l \mathrm{ei}^{29}$.

${ }^{28}$ SIEYÈS, Joseph Emmanuel. A constituinte burguesa, p. 79.

${ }^{29}$ SIEYÈS, Joseph Emmanuel. A constituinte burguesa, p. 82-83. 
TELES, Tayson Ribeiro. Para que serve e/ou a quem serve uma Constituição? Jusfilosofias à luz de Sieyès, Lassalle, Hesse e Haberle. Revista Eletrônica Direito e Política, Programa de Pós-Graduaç̧ão Stricto Sensu em Ciência Jurídica da UNIVALI, Itajaí, v.13, n.1, $1^{\circ}$ quadrimestre de 2018. Disponível em: www.univali.br/direitoepolitica - ISSN 1980-7791

Vê-se que Sieyès não foi um utópico por utópico. Da asserção retro dita é perceptível que ele assume saber que o parlamento não foi feito para tratar de assuntos particulares das pessoas. A vida corre de pressa, todos os dias inúmeras pessoas morrem, outras nascem. De fato, um parlamento cuida de questões gerais e vê mesmo todos os cidadãos como sendo uma única coisa: massa. Sieyés não é contra essa generalização legislativa. O problema está, segundo ele, em os poderosos além de enxergarem o povo como uma massa, manobrarem tal massa em um plasma de realizações apenas de seus interesses - de suas classes.

Uma grande questão suscitada por Sieyès é que não é por ser impossível que o Estado cuide de todos os cidadãos, atendendo aos seus particulares desejos, que este Estado pode privilegiar alguns cidadãos. É impraticável que todos tenham as mesmas coisas, trabalhem em iguais profissões, vistam as mesmas roupas etc., mas é plenamente crível que todos tenham acesso a médicos em hospitais públicos sempre que precisarem, a bons professores e estrutura adequada nas escolas e universidades, a dignos salários, a casas para viver, em resumo, ao mínimo necessário/existencial para ser/estar feliz.

Por fim, evidencia-se que as construções de Sieyès, que as erigiu ainda no século XVIII - deve-se frisar isso para lembrar-se que os principais problemas políticos e sociais do mundo existem há tempos -, são interessantes, nos fazem refletir muito sobre nosso país, mas ele mesmo sabia que suas ideias eram quase impraticáveis. Vociferou o revolucionário que "não é possível acolher, ao mesmo tempo, a petição do Terceiro Estado e a defesa dos privilegiados, sem derrubar as noções mais seguras" ${ }^{\prime \prime 3}$. Quis dizer ele: somente conseguiremos almejar uma sociedade mais justa se todos tiverem suas demandas acolhidas e não é possível agradar ricos e pobres sem que sejam quebrados conceitos, costumes e princípios que há tempos são hipócrita e seguramente fixos, como, por exemplo, a ideia de que é bom e bonito acumular riquezas e não há problemas em explorar os outros.

30 SIEYĖS, Joseph Emmanuel. A constituinte burguesa, p. 30. 
TELES, Tayson Ribeiro. Para que serve e/ou a quem serve uma Constituição? Jusfilosofias à luz de Sieyès, Lassalle, Hesse e Haberle. Revista Eletrônica Direito e Política, Programa de Pós-Graduação Stricto Sensu em Ciência Jurídica da UNIVALI, Itajaí, v.13, n.1, $1^{0}$ quadrimestre de 2018. Disponível em: www.univali.br/direitoepolitica - ISSN 1980-7791

\section{QUAL DEVE SER A ESSÊNCIA DE UMA CONSTITUIÇÃO? PONDERAÇõES EM LASSALLE}

Passa-se a analisar a "A Essência da Constituição", de Ferdinand Lassalle. Este democrata alemão do século XIX, nesta obra, basicamente, defendeu intransigentemente o sufrágio universal igual e direto para os operários de sua época, a fim de que por meio do voto livre os mais pobres pudessem conquistar o Estado e implementar por meio dele as reformas sociais necessárias para melhorar a vida do povo.

O autor inicia a obra dimanando que o fato de escrevê-la não o torna diferente das outras pessoas nem exige dele conhecimentos específicos, pois todos sabem, no fundo da vida, o que é o correto a se fazer, mesmo os carrascos, os exploradores, que se pararem e pensarem não agem maleficamente. No decorrer de todo o texto ele vai se divagando sobre o que seria, como diz o título da obra, a essência de uma Constituição. Logo nas linhas inauguradoras diz:

Que é uma Constituição? Qual é a verdadeira essência de uma Constituição? Em todos os lugares e a qualquer hora, à tarde, pela manhã e à noite, estamos ouvindo falar da Constituição e de problemas constitucionais. Na imprensa, nos clubes, nos cafés e nos restaurantes, é este o assunto obrigatório de todas as conversas ${ }^{31}$. E apesar disso, ou por isso mesmo, formulamos em termos precisos esta pergunta: Qual será a verdadeira essência, o verdadeiro conceito de uma Constituição? Estou certo de que, entre essas milhares de pessoas que dela falam, existem muito poucos que possam dar-nos uma resposta satisfatória. ${ }^{32}$

Lassalle, visivelmente, provoca nosso pensar na direção de respondermos se realmente sabemos o que é uma Constituição (?). Durante a obra ele percorre um

\footnotetext{
31 Deve-se lembrar que era assim em sua época. Hoje em dia, desde o começo do século XX pelo menos, as pessoas não conversam mais sobre política com o mesmo afinco. O rádio, a TV, os computadores, smartphones, tablets, o facebook, o whatsApp e demais instrumentos de alienação erigidos pelos donos do capital/poder, que os constroem com a desculpa de tornar a sociedade mais ágil e em verdade têm o mote de forjarem uma sociedade doentemente consumista - fazem a maioria das pessoas conversarem sobre tudo, exceto e raramente sobre política, sobre economia, filosofia. Como disse o sociólogo polonês Zygmunt Bauman, em sua ideia da modernidade líquida, vive-se atualmente em etapa na qual tudo que era sólido se liquidificou, na medida em que nossos acordos são temporários, passageiros, válidos apenas até novo aviso, e vivemos relações de amizade virtuais, tênues e artificiais, que se quebram ou se constroem como muita facilidade.
}

32 LASSALLE, Ferdinand. A essência da Constituição. Tradução de João de Almeida. Rio de Janeiro: Lúmen Juris, 2009, p. 5. 
TELES, Tayson Ribeiro. Para que serve e/ou a quem serve uma Constituição? Jusfilosofias à luz de Sieyès, Lassalle, Hesse e Haberle. Revista Eletrônica Direito e Política, Programa de Pós-Graduação Stricto Sensu em Ciência Jurídica da UNIVALI, Itajaí, v.13, n.1, 10 quadrimestre de 2018. Disponível em: www.univali.br/direitoepolitica - ISSN 1980-7791

caminho metodológico diferenciado rumo a chegar a alguma resposta para esta pergunta central. O autor busca um conceito de Constituição comparando esta norma com outro conceito, o de lei. É como se dissesse que não sabe o que é uma Constituição, mas sabe o que ela não é.

Veja-se:

Qual a diferença entre uma Constituição e uma lei? Ambas (...) têm, evidentemente, uma essência genérica comum. Uma Constituição [...] necessita de aprovação legislativa, isto é, tem que ser também lei. Todavia, não é uma lei como as outras, uma simples lei: é mais do que isso. Entre os dois conceitos não existem somente afinidades; há também dessemelhanças. Estas fazem com que a Constituição seja mais do que simples lei e eu poderia demonstrá-las com centenas de exemplos. O país, por exemplo, não protesta pelo fato de constantemente serem aprovadas novas leis; pelo contrário, todos nós sabemos que se torna necessário que todos os anos seja criado maior ou menos número de leis. Mas, quando mechem na Constituição, protestamos e gritamos: "Deixem a Constituição!" Qual é a origem dessa diferença? (...) no espírito unânime dos povos, uma Constituição deve ser qualquer coisa de mais sagrado, de mais firme e de mais imóvel que uma lei comum. ${ }^{33}$

Lassalle, de fato, incita pensamentos sobre se realmente sabemos o que é uma Constituição (?). Lembra o teórico que se tem o vício de dizer que a Constituição é a lei fundamental de uma nação. Mas, ao dizer-se isso, narra, ainda se continua no mesmo lugar, pois exsurgirá outra indagação: qual a diferença ente uma lei e uma lei fundamental? Parece filosófico demais, porém, de fato, será que se pode dizer que se sabe o que é uma Constituição? Pode-se ir ao verbo e pensar: é óbvio que a Constituição é o documento firmado quando ocorre a constituição/produção de uma nação, de um país, momento em que toda a sua estrutura é organizada/criada.

Com espeque nisso, se se alçar o caminho proposto pelo verbo indicativo de criação (constituir), como ficam as nações que já existem e fazem novas Constituições, como fez o Brasil em 1988 e em outras seis vezes, nas constituições

33 LASSALLE, Ferdinand. A essência da Constituição, p. 7-8. 
TELES, Tayson Ribeiro. Para que serve e/ou a quem serve uma Constituição? Jusfilosofias à luz de Sieyès, Lassalle, Hesse e Haberle. Revista Eletrônica Direito e Política, Programa de Pós-Graduação Stricto Sensu em Ciência Jurídica da UNIVALI, Itajaí, v.13, n.1, 10 quadrimestre de 2018. Disponível em: www.univali.br/direitoepolitica - ISSN 1980-7791

de 1891, 1934, 1937, 1946, 1967 e 1969³4 Diz-se nessas sete vezes, pois na primeira Constituição, a de 1824, sim pode-se dizer que houve a constituição/criação do "Brasil". Lassalle passa o texto inteiro provocando e indagando sobre se de fato se sabe mesmo o que é uma Constituição (?). No entanto, pela metade da obra ele começa a aceitar esta como sendo a norma fundamental de uma nação, pois, de fato, é uma lei básica que serve de fundamento para a criação de outras.

Ao falar em fundamentos, ele produz provocação sobre se saber quais seriam os fundamentos que eliciam a criação da própria Constituição? É uma pergunta bem interessante, senão veja-se: nós mesmos, às vezes, dizemos que viemos de Deus, mas nos perguntamos de onde ele vem, não é verdade? De onde viria a Constituição? O autor responde filosoficamente dizendo que os fundamentos de uma Constituição são forças ativas que fazem com que ela seja compulsoriamente o que ela é, pois ela não poderia ser outra coisa. Complexo? Pode parecer muito filosófico, todavia, basicamente, Lassalle esclarece que a Constituição não tem como ser definida, pois ela é somente o que ela poderia ser. Sem ela não se teria o Estado. Sem Estado não teríamos a nós, pois já teríamos matado a nós mesmos em épocas pretéritas de lutas materiais por recursos, notadamente alimentares e sexuais, como fazem atualmente os animais ${ }^{35}$.

Estas forças ativas, Lassalle as chama de Fatores Reais do Poder. O que são tais fatores? Lassalle os explica com um exemplo bem interessante. Diz, da Prússia onde escreveu sua obra:

Vamos supor, por um momento, que um grande incêndio irrompeu e que nele queimaram-se todos os arquivos do Estado, todas as bibliotecas públicas, que o sinistro destruísse também a tipografia concessionária onde se imprimia a Coleção Legislativa e que ainda, por uma triste coincidência -

\footnotetext{
34 Existe grande divergência entre vários estudiosos do Direito brasileiro quanto a se saber se a Emenda Constitucional (EC) n. ${ }^{\circ} 1$ de 1969 pode ou não ser considerada uma Constituição, na medida em que modificou quase por inteira a Constituição de 1967. Particularmente, acreditamos que, como - nome diz, foi apenas uma Emenda, pois não houve em 1969 a instauração de uma Constituinte/comissão para a elaboração de uma nova ordem legal no país. O Próprio site da presidência da República afirma ter havido Constituições em 1824, 1891, 1934, 1937, 1946, 1967, uma Emenda à Constituição de 1967, em 1969, e a Constituição de 1988.

${ }^{35}$ Cremos que ainda fazemos, conquanto atenuadamente em cotejo ao passado, mas fazemos.
} 
TELES, Tayson Ribeiro. Para que serve e/ou a quem serve uma Constituição? Jusfilosofias à luz de Sieyès, Lassalle, Hesse e Haberle. Revista Eletrônica Direito e Política, Programa de Pós-Graduação Stricto Sensu em Ciência Jurídica da UNIVALI, Itajaí, v.13, n.1, $1^{0}$ quadrimestre de 2018. Disponível em: www.univali.br/direitoepolitica - ISSN 1980-7791

estamos no terreno das suposições -, igual desastre ocorresse em todas as cidades do país, desaparecendo inclusive todas as bibliotecas particulares onde existissem coleções, de tal maneira que em toda a Prússia não fosse possível achar um único exemplar das leis do país. Suponhamos que um país, por causa de um sinistro, ficasse sem nenhuma das leis que o governavam e que, por força das circunstâncias, fosse necessário decretar novas leis. Neste caso, o legislador, completamente livre, poderia fazer leis de capricho ou de acordo com o seu próprio modo de pensar? [...] suponhamos que os senhores respondam: visto que as leis desapareceram e que vamos redigir outras completamente novas, desde os alicerces até o telhado, nelas não reconheceremos à monarquia as prerrogativas de que até agora gozou ao amparo das leis destruídas; mais ainda, não respeitaremos prerrogativas nem atribuições de espécie alguma. Enfim, não queremos a monarquia. O monarca responderia assim: Podem estar destruídas as leis, porém a realidade é que o exército subsiste e me obedece, acatando minhas ordens; a realidade é que os comandantes dos arsenais e quartéis põem na rua os canhões e as baionetas quando eu ordenar. Assim, apoiado neste poder real, efetivo, das baionetas e dos canhões, não tolero que venham me impor posições e prerrogativas em desacordo comigo. ${ }^{36}$

Interessante, não? Claro que Lassalle fala de monarquia, momento em que os Reis eram respeitados apenas por serem o que eram - o povo acreditava que estes eram divinos, pois tais realezas mandavam escribas incutirem suas divindades em escrituras sagradas -, e hoje se vive, no Brasil, em uma República presidencialista. Mas, e se um incêndio como esse ocorresse no Brasil de hoje: quais seriam os fatores reais de poder? O que subsistiria?

Esqueça-se que nossas leis estão todas digitalizadas e disponíveis na internet ou conjecture-se que estas foram apagadas por ferozes hackers. Quais seriam nossos fatores reais de poder? O Exército Brasileiro à disposição do presidente da República? A burguesia e o grande empresariado industrial e agrário? Os parlamentares - que também são majoritariamente empresários? O povo?

Lassalle diz que o Rei (governante) é um fator real de poder. Além disso, enumera outros fatores, como: a aristocracia (os donos de terras); a burguesia (que à época

\footnotetext{
36 LASSALLE, Ferdinand. A essência da Constituição, p. 13-14.
} 
TELES, Tayson Ribeiro. Para que serve e/ou a quem serve uma Constituição? Jusfilosofias à luz de Sieyès, Lassalle, Hesse e Haberle. Revista Eletrônica Direito e Política, Programa de Pós-Graduaç̧ão Stricto Sensu em Ciência Jurídica da UNIVALI, Itajaí, v.13, n.1, $1^{\circ}$ quadrimestre de 2018. Disponível em: www.univali.br/direitoepolitica - ISSN 1980-7791

era constituída por pequenos comerciantes, ferreiros etc., e hoje, pelo menos no Brasil, é integrada pelos ricos, dado que "acabou" a nobreza e o clero isolou-se em catedrais); os banqueiros; e a classe operária. Com tal enumeração, Lassalle chegou, pois, à conclusão de que uma Constituição nada mais é do que uma folha de papel repleta de fatores reais do poder. Sendo que a relevância de sua teoria é a afirmação de que, caso uma Constituição não possua os reais fatores do poder, ela será apenas uma folha de papel.

O que quis ele asseverar? Lassalle quis afirmar que uma Constituição para ser efetiva/concreta e não se afigurar apenas como uma folha de papel deve contemplar em suas normas direitos, deveres, perspectivas e possibilidades que envolvam todos os setores da sociedade. O problema, segundo ele, é que este envolvimento deveria ocorrer de forma igual e proporcional para todas as "camadas" da sociedade, mas não ocorre.

Noutro enfoque, falando em servidores públicos, Lassalle narrou que "[...] geralmente os Reis têm ao seu serviço melhores servidores do que o povo. Os daqueles são práticos e os do povo são retóricos; aqueles possuem o instinto de agir no momento oportuno, estes fazem discursos nas horas em que outros dão ordens para que os canhões sejam postos na rua contra o povo"37. É verdade isso, não? Perceba-se, por exemplo, como a polícia militar age para reprimir movimentos grevistas de classes numerosas, como professores? Por que são tão truculentos, efetivos e eficientes em sua missão de acabar com tais movimentos? Muitas vezes os próprios policiais, que são seres humanos e pensam, têm familiares naqueles movimentos, mas esquecem-se disso e tratam todos como uma massa, por quê?

Que tipo de ordem o Estado, por meio de seu governante maior - o chefe das polícias, dá a estes militares para que eles erijam dentro de si uma programação psicológica por meio da qual fiquem instantaneamente frios e consigam agredir professores, estudantes, pais de alunos etc. imotivadamente? O fazem apenas

\footnotetext{
37 LASSALLE, Ferdinand. A essência da Constituição, p. 40-41.
} 
TELES, Tayson Ribeiro. Para que serve e/ou a quem serve uma Constituição? Jusfilosofias à luz de Sieyès, Lassalle, Hesse e Haberle. Revista Eletrônica Direito e Política, Programa de Pós-Graduação Stricto Sensu em Ciência Jurídica da UNIVALI, Itajaí, v.13, n.1, 10 quadrimestre de 2018. Disponível em: www.univali.br/direitoepolitica - ISSN 1980-7791

para garantirem seus empregos? Mas, não são concursados? Seriam acusados de prevaricação? Será que se sentem sendo o próprio Estado/poder?

Por que o ser humano tem uma espécie de fascínio/submissão pelo poder? Por que o povo leigo ${ }^{38}$ ao ver um governante quer com ele tirar uma foto para mostrar aos outros do povo, como se quisesse dizer que é alguém importante, pois está próximo dos poderosos? Por que nas repartições públicas do Brasil existem fotografias oficiais do(a) presidente da República em paredes? Seriam resquícios do absolutismo? O absolutismo acabou mesmo? Por que apenas os governantes têm ao seu dispor os melhores servidores e ajudantes - os pós-graduados, especialistas, mestres, doutores etc.? Por que os melhores servidores do Estado não estão nos hospitais tentando acabar com suas filas? Nas escolas alfabetizando as crianças?

Ademais, finalizando a exígua obra, Lassalle rememora que, então, "os problemas constitucionais não são problemas de direito, mas de poder; a verdadeira Constituição de um país somente tem por base os fatores reais e efetivos do poder $[\ldots]^{\prime \prime 39}$. Torna-se clarividente, logo, que uma Constituição efetiva, concreta e real tem de abarcar todos os fatores de poder da sociedade, ou seja, direcionar seus direitos e garantias para todos, em tese indistintamente, e sem privilégios exacerbados, descabidos, vergonhosos e ridículos, como foros privilegiados, imunidades etc. Além disso, deve possibilitar tributos justos e proporcionais à renda das pessoas e implementar justiça e desenvolvimento sociais.

\footnotetext{
38 Num bom sentido, posto que nos referimos apenas àqueles que ainda não sabem da existência de discursos, ideologias veladas etc., pois ser leigo não tem a ver com ser ou não inteligente. Inteligência remete ao latim intelligencia, que significa "fazer escolhas", "interligar as coisas", ou seja, inteligente é quem sabe interligar fatos, processos, pensar. Por exemplo, para ir ao mercado comprar pão, sabemos que devemos nos deslocar até lá, pagar pelo pão e voltar para casa; somos inteligentes. O ser leigo ou não se refere somente ao conhecimento acumulado, aquele que é obtido em instituições de ensino e sob a orientação de outros seres humanos, não sendo obrigatório buscálo (vai à escola quem quer/tem a oportunidade). Além do que, existe ainda a sabedoria, um conceito um pouco filosófico, mas que indica alguém com elevada capacidade de reflexão, parcimônia etc.
}

39 LASSALLE, Ferdinand. A essência da Constituição, p. 47. 
TELES, Tayson Ribeiro. Para que serve e/ou a quem serve uma Constituição? Jusfilosofias à luz de Sieyès, Lassalle, Hesse e Haberle. Revista Eletrônica Direito e Política, Programa de Pós-Graduação Stricto Sensu em Ciência Jurídica da UNIVALI, Itajaí, v.13, n.1, $1^{\circ}$ quadrimestre de 2018. Disponível em: www.univali.br/direitoepolitica - ISSN 1980-7791

\section{DEVE-SE VER UMA CONSTITUIÇÃO COMO LEI? REFLEXÕES EM HESSE}

Procede-se à análise de "A Força Normativa da Constituição", de Konrad Hesse. Em tal obra, originalmente concebida em 1959, este autor se contrapõe às ideias de Lassalle que se acabou de ver, o fazendo porém 97 anos depois que Lassalle as teve e 95 anos depois de sua morte. Afirma Hesse que Lassalle estava errado ao dizer que questões constitucionais não são questões jurídicas, mas sim políticas. Hesse diz que tal ideia Lassalliana afigura-se sem respaldo na medida em que uma Constituição que não represente, em si mesma, todos os fatores reais de poder enumerados por Lassalle não necessariamente será apenas uma folha de papel em branco como aquele estudioso defendeu.

Para Hesse, a Constituição, o texto escrito da norma fundamental, contém "[...] ainda que de forma limitada, uma força própria, motivadora e ordenadora da vida do Estado"40, bem como diz ele que o Direito Constitucional, por ser um ramo jurídico, é de per si normativo - tem força. Deve-se compreender esta visão de Hesse na medida em que ele foi por muito tempo juiz do Tribunal Constitucional Federal alemão, um órgão análogo ao brasileiro Supremo Tribunal Federal (STF). Portanto, como juiz tinha uma visão dogmática e positivista de que sim todas as leis escritas em papéis, bem como a Constituição de seu país, tinham força, aplicabilidade e normatividade, quer ou não representassem fatores reais de poder.

No entanto, malgrado esse pensamento, Hesse não possuía uma visão apequenada. No decorrer da obra vai desenvolvendo melhor seu pensamento e objetiva, basicamente, criar um "condicionamento recíproco existente entre a Constituição jurídica e a realidade político-social"41, ou seja, tenta ele aceitar algumas ideias de Lassalle, mas coaduná-las em parte ao fato de que sim uma Constituição enquanto documento escrito - uma "folha de papel" - vale e representa muita coisa, notadamente aspectos jurídico-normativos.

40 HESSE, Konrad. A força normativa da Constituição. Tradução de Gilmar Ferreira Mendes. Porto Alegre: Fabris Editor, 1991, p. 11.

41 HESSE, Konrad. A força normativa da Constituição, p. 13 
TELES, Tayson Ribeiro. Para que serve e/ou a quem serve uma Constituição? Jusfilosofias à luz de Sieyès, Lassalle, Hesse e Haberle. Revista Eletrônica Direito e Política, Programa de Pós-Graduação Stricto Sensu em Ciência Jurídica da UNIVALI, Itajaí, v.13, n.1, $1^{\circ}$ quadrimestre de 2018. Disponível em: www.univali.br/direitoepolitica - ISSN 1980-7791

Dimana o autor que as pessoas que veem a Constituição apenas como uma norma escrita olvidam que sim há outros fatores imanentes à ordem básica estatal, bem como aqueles que a concebem apenas como sendo um plexo de aspectos sociais e políticos esquecem-se de que seu significado maior é estabelecer uma ordenação - do povo - jurídica, ou seja, servir de lei. Suas ideias são muito relevantes porque nos deram a noção de que a Constituição tem força de lei e deve ser cumprida, não sendo apenas um documento que descreve como deve funcionar o Estado. Afinal, "a Constituição, quando procura imprimir ordem e conformação à realidade política e social (...) não configura (...) apenas expressão de um ser, mas também de um dever-ser"42.

Ediciona Hesse que "embora a Constituição não possa, por si só, realizar nada, ela pode impor tarefas"43. É deveras bela esta colocação. Por certo, as letras e caracteres gráficos outros presentes na CRFB/88, por exemplo, nada dizem signologicamente ou fazem materialmente, mas estabelecem ordens e impõem tarefas a todos os cidadãos, notadamente aos governantes. Aqui reside um ponto importante para se pensar sobre as razões por que a CRFB/88 não é cumprida, mormente na prestação de muitos dos direitos sociais que estampa. Será que ela não é cumprida porque as pessoas a quem ela mesma dá ordem para cumpri-la fingem não auscultá-la? Diz-se isso, pois os mandamentos para que ela seja cumprida estão todos nela. Mas, não é só isso: além de as pessoas responsáveis por seu cumprimento não a cumprirem existem muitas ideologias e objetivos velados presentes na CRFB/88 desde sua produção, o que impossibilita que nós mesmos, cidadãos de bem, honestos, trabalhadores, tenhamos acesso às benesses que ela poderia nos oferecer.

Pois bem, esta imposição de tarefas a que Hesse se refere ele chama de vontade de Constituição e diz ele que ela:

Baseia-se na compreensão da necessidade e do valor de uma ordem normativa inquebrantável, que proteja o Estado contra o arbítrio desmedido e disforme. Reside, igualmente, na compreensão de que essa ordem constituída é mais do que

\footnotetext{
42 HESSE, Konrad. A força normativa da Constituição, p. 15.

43 HESSE, Konrad. A força normativa da Constituição, p. 19.
} 
TELES, Tayson Ribeiro. Para que serve e/ou a quem serve uma Constituição? Jusfilosofias à luz de Sieyès, Lassalle, Hesse e Haberle. Revista Eletrônica Direito e Política, Programa de Pós-Graduação Stricto Sensu em Ciência Jurídica da UNIVALI, Itajaí, v.13, n.1, 10 quadrimestre de 2018. Disponível em: www.univali.br/direitoepolitica - ISSN 1980-7791

uma ordem legitimada pelos fatos (e que por isso, necessita e está em constante processo de legitimação). Assenta-se também na consciência de que, ao contrário do que se dá com uma lei do pensamento, essa ordem não logra ser eficaz sem o concurso da vontade humana. Essa ordem adquire e mantém sua vigência através de atos de vontade. ${ }^{44}$

Hesse, como se vê, não está dizendo como a Constituição é e sim como ela deveria ser. Essa vontade a que ele se refere nos é óbvia a todos. Sabemos que para fazer qualquer coisa o homem precisa ter volição, a qual geralmente sempre caminha pari passu com o desejo e com o interesse, notadamente o econômico. Ocorre que o problema envolto nesta vontade é que ela deveria ser a vontade da maioria do povo. Mas, não se faz referência à maioria "metade mais um", pois esta exclui $49 \%$ do povo. Ao contrário, deve-se fomentar a ideia de uma maioria que tenha realmente a representatividade de todos os setores da sociedade, como já nos disseram os mencionados Sieyès e Lassalle, cada um ao seu modo.

Sabe-se ser impraticável que todos os integrantes de uma nação participem da feitura de uma Constituição, mas, pelo menos todos os grupos sociais, classes profissionais etc., deveriam ter a chance de ter representantes que pudessem opinar e ter voto de igual peso ao dos ricos, neste processo de feitura. O que não ocorre em boa parte do mundo nem ocorreu no Brasil, pois a mídia pátria prega ter havido grande participação popular na engendração da CRFB/88, inclusive o próprio Ulysses Guimarães em seu discurso promulgador o disse, mas, em verdade, apenas participarem da construção da Constituição setores específicos e estratégicos, o resto foi teatro, arte maléfica, jogos de palavras/ideologias. ${ }^{45}$

Entrementes, entronou Hesse que ao se analisar uma Constituição, "a interpretação adequada é aquela que consegue concretizar de forma excelente, o

\footnotetext{
44 HESSE, Konrad. A força normativa da Constituição, p. 19.

45 Para se ter uma ideia, como conta Pilatti (2008), para cada proposição popular ao texto da Constituição de 1988 eram necessárias 30 mil assinaturas. Foram protocoladas mais de 11 mil indicações populares de textos para a CRFB/88 - cada uma com mais de 30 mil assinaturas. 122 foram analisadas pelos constituintes e apenas 19 foram aprovadas.
} 
TELES, Tayson Ribeiro. Para que serve e/ou a quem serve uma Constituição? Jusfilosofias à luz de Sieyès, Lassalle, Hesse e Haberle. Revista Eletrônica Direito e Política, Programa de Pós-Graduação Stricto Sensu em Ciência Jurídica da UNIVALI, Itajaí, v.13, n.1, 10 quadrimestre de 2018. Disponível em: www.univali.br/direitoepolitica - ISSN 1980-7791

sentido (...) da proposição normativa dentro das condições reais dominantes numa determinada situação"46. Além do que:

A finalidade de uma proposição constitucional e sua nítida vontade normativa não devem ser sacrificadas em virtude de uma mudança da situação. [Dessa forma], se o sentido de uma proposição normativa não pode mais ser realizado, a revisão constitucional afigura-se inevitável. ${ }^{47}$

É como se Hesse quisesse dizer que a evolução da sociedade (as mudanças, os fatos sociais, os fatores reais de poder do Lassalle etc.), não são capazes de obliterar a vontade normativa que a Constituição tem - que é a de regular e controlar o Estado e seus cidadãos, notadamente o povo pobre -, então, nesse viés, sendo constatada a real impraticabilidade de certas normas constitucionais em face de mudanças sociais, a solução é mudar a Constituição e não deixar de cumpri-la (bem cômodo). Este pensamento de Hesse é importante para se pensar na Constituição como de fato uma lei, que deve ser cumprida, porquanto foi feita para tal. No caso do Brasil, o problema, então, não está na Constituição e sim em quem deveria cumpri-la? Sim, mas, mais gravemente, o problema está em quem fez e como fez a Constituição.

Por final, Hesse cerra a obra dizendo que "(..) a Constituição jurídica não significa simples pedaço de papel, tal como caracterizada por Lassalle. Ela não se afigura impotente para dominar, efetivamente, a distribuição de poder (...), não está desvinculada da realidade histórica concreta de seu tempo"48. Hesse está correto e prova disso é a atual supervalorização que os países ocidentais têm dado às suas Constituições, notadamente em sede de suas Cortes Supremas, quando as normas máximes das nações têm servido de baliza para julgamentos sobre temas polêmicos antes jamais pensados, como união homoafetiva, liberação de drogas, aborto, pesquisas com células embrionárias, eutanásia etc. Por certo, é mesmo às Constituições e seus valores supremos que se deve recorrer sempre em última instância.

\footnotetext{
46 HESSE, Konrad. A força normativa da Constituição, p. 22.

47 HESSE, Konrad. A força normativa da Constituição, p. 23.

48 HESSE, Konrad. A força normativa da Constituição, p. 25.
} 
TELES, Tayson Ribeiro. Para que serve e/ou a quem serve uma Constituição? Jusfilosofias à luz de Sieyès, Lassalle, Hesse e Haberle. Revista Eletrônica Direito e Política, Programa de Pós-Graduação Stricto Sensu em Ciência Jurídica da UNIVALI, Itajaí, v.13, n.1, 10 quadrimestre de 2018. Disponível em: www.univali.br/direitoepolitica - ISSN 1980-7791

\section{COMO INTERPRETAR UMA CONSTITUIÇÃO? PONDERAÇÕES EM HABERLE}

Passa-se a enunciar comentários sobre a última obra das quatro que se prenunciou como basilares para o Direito Constitucional, a saber: "Hermenêutica Constitucional: a sociedade aberta dos intérpretes da Constituição", de Peter Haberle. Nesta obra, o pesquisador propugna a possibilidade da adoção de uma hermenêutica/interpretação da Constituição que seja feita por todos os cidadãos de uma dada nação. Para ele, tendo a Constituição um papel fundante na nação, todo aquele que na nação viver deve ter a capacidade/poder e o direito de interpretar sua Constituição. É uma visão radical in faciem do atual modelo mundial em que as Constituições são interpretadas apenas por juízes de tribunais superiores, o que no Brasil é uma função exclusiva do STF.

Promana o autor que "os critérios de interpretação constitucional hão de ser tanto mais abertos quanto mais pluralista fora a sociedade"49. Ele propõe tal abertura, pois diz que os destinatários da norma constitucional são participantes ativos da sociedade, estão nas igrejas, nas organizações sindicais, nas associações de bairro etc. Suas ideias, basicamente, indicam que seria ideal que a sociedade participasse não apenas da produção da Constituição - quando é representada pelos integrantes do Poder Constituinte Originário -, mas também da interpretação e aplicação da Constituição quando ela passar a viger.

Enaltece, com efeito, que a:

(...) interpretação é um processo aberto. Não é, pois, um processo de passiva submissão, nem se confunde com a recepção de uma ordem. (...) conhece possibilidades e alternativas diversas. A ampliação do círculo dos intérpretes aqui sustentada é apenas a consequência da necessidade, por todos defendida, de integração da realidade no processo de interpretação. (...) se se reconhece que a norma não é uma decisão prévia, simples e acabada, há de se indagar sobre os participantes no seu desenvolvimento funcional. (...) Qualquer intérprete é orientado pela teoria e pela práxis.

49 HABERLE, Peter. Hermenêutica Constitucional: a sociedade aberta dos intérpretes da Constituição. 2. ed. Tradução de Gilmar Ferreira Mendes. Porto Alegre: Fabris Editor, 2002, p. 13. 
TELES, Tayson Ribeiro. Para que serve e/ou a quem serve uma Constituição? Jusfilosofias à luz de Sieyès, Lassalle, Hesse e Haberle. Revista Eletrônica Direito e Política, Programa de Pós-Graduação Stricto Sensu em Ciência Jurídica da UNIVALI, Itajaí, v.13, n.1, $1^{\circ}$ quadrimestre de 2018. Disponível em: www.univali.br/direitoepolitica - ISSN 1980-7791

Todavia, essa práxis não é, essencialmente, conformada pelos intérpretes oficiais da Constituição. ${ }^{50}$

Essa sua concepção sobre uma factível abertura de interpretação da Constituição inspirou no Brasil a aceitação da figura do amicus curiae, o qual nomeia uma pessoa estudiosa de alguma área que é ouvida pelo STF em casos específicos em que se precise da opinião de especialistas, na medida em que os Ministros daquela Corte não sabem de tudo. Por exemplo, quando do Julgamento sobre a liberação de pesquisas com células-tronco embrionárias, na Ação Direta de Inconstitucionalidade (ADIN) n.o 3510, em 29 de maio de 2008, os Ministros do STF auscultaram diversos especialistas em medicina e biologia, a fim de chegarem a uma conclusão sobre quando de fato começa a vida humana e se as célulastronco embrionárias poderiam ou não ser usadas em experimentos - o que foi julgado procedente e desde lá é permitido no país, com algumas ressalvas.

Haberle aduz que "limitar a hermenêutica constitucional aos intérpretes 'corporativos' ou autorizados (...) pelo Estado significa um empobrecimento. (...) um entendimento (...) não pode renunciar à fantasia e à força criativa dos intérpretes não corporativos" ${ }^{\prime 1}$. Isso, pois:

A Corte Constitucional haverá de interpretar a Constituição em correspondência com a sua atualização pública; (...) pois, o processo constitucional formal não é a única via de acesso ao processo de interpretação constitucional. (...) o Constitucionalista é apenas um mediador. O raio de interpretação normativa amplia-se graças aos 'intérpretes da Constituição da sociedade aberta'. Eles são os participantes fundamentais no processo de (...) descoberta e de obtenção de direito. ${ }^{52}$

Por fim, pondo a termo a análise da obra, a qual é bem pequena em páginas, pode-se dizer que Haberle é tão enfático em sua proposição de que todos possam atuar como intérpretes de Constituições, pois acredita que "os interesses públicos ou $(\ldots)$ os interesses aptos a serem generalizados" 53 somente podem ser

\footnotetext{
50 HABERLE, Peter. Hermenêutica Constitucional, p. 30-31.

51 HABERLE, Peter. Hermenêutica Constitucional, p. 34.

52 HABERLE, Peter. Hermenêutica Constitucional, p. 42-43.

53 HABERLE, Peter. Hermenêutica Constitucional, p. 46.
} 
TELES, Tayson Ribeiro. Para que serve e/ou a quem serve uma Constituição? Jusfilosofias à luz de Sieyès, Lassalle, Hesse e Haberle. Revista Eletrônica Direito e Política, Programa de Pós-Graduaç̧ão Stricto Sensu em Ciência Jurídica da UNIVALI, Itajaí, v.13, n.1, $1^{\circ}$ quadrimestre de 2018. Disponível em: www.univali.br/direitoepolitica - ISSN 1980-7791

defendidos pelos membros práticos da sociedade, o povo pobre, os trabalhadores. Os juízes dos portentosos tribunais revestidos a ouro nem sempre pensam efetiva e ideologicamente ${ }^{54}$ no bem do povo, afinal estão no poder e não integram tal povo. Mesmo se um dia um algum deles foi pobre, ao pisar nos palácios do poder, seus pés irrefragavelmente se contaminam pelo ardil comportamento dos que enojam o povo. Praticamente toda pessoa muda no e pelo poder. Ao comer comidas diferentes, tidas como melhores, por exemplo, pensa o "novo rico" que já não vale à pena pensar no Outro.

Pergunta-se, então, pois, seria possível no Brasil que todos nós interpretássemos a CRFB/88? Complexo, não? Como seria? Todos gritando rente a balcões de repartições públicas com um exemplar da Constituição a exalar uma interpretação particular sobre certo dispositivo e a requerer a concessão de algum direito? Qual a solução para este problema da interpretação constitucional? É certo que apenas Ministros do STF, que, com raras exceções, sempre são juristas que nunca passaram fome, são professores doutores formados na Alemanha, França ou Itália, interpretem a Constituição? Onde fica o povo? Onde está atualmente o povo? No vale da fome, da ausência de educação, de saúde, de saneamento básico, de perspectivas várias de futuro? No vale do sonho de uma carteira de trabalho assinada com o carimbo de 1 (um), apenas 1 , salário mínimo?

\section{CONSIDERAÇÕES FINAIS}

Como percebido, se quis neste artigo, refletir filosoficamente sobre a natureza, a razão de ser, os objetivos e as serventias de uma Constituição. O texto teve muitas perguntas, pois suas ponderações foram perscrutadas sobre o trilho de perspectivas filosóficas, portanto especulativas, de quatro autores e suas renomadas obras filosóficas integrantes da área do Direito Constitucional e da Teoria da Constituição: Sieyès, Lassalle, Hesse e Haberle. Por isso, como denotou o título, este foi um esforço teórico jusfilosófico. O problema de pesquisa sintetizou-se à seguinte indagação: para que serve e/ou a quem serve uma Constituição?

\footnotetext{
54 Num sentido de ideia e não da coisa velada ou encoberta.
} 
TELES, Tayson Ribeiro. Para que serve e/ou a quem serve uma Constituição? Jusfilosofias à luz de Sieyès, Lassalle, Hesse e Haberle. Revista Eletrônica Direito e Política, Programa de Pós-Graduação Stricto Sensu em Ciência Jurídica da UNIVALI, Itajaí, v.13, n.1, 10 quadrimestre de 2018. Disponível em: www.univali.br/direitoepolitica - ISSN 1980-7791

Foi visto que em "A Constituinte Burguesa", Sieyès surgiu com a ideia de poder existir um Poder além dos poderes instituídos, um poder que seja imanente à nação, o que chamou de Poder Constituinte. Viu-se, também, em "A Essência da Constituição", que Lassalle cunhou a concepção sociológica da Constituição, dizendo que esta deve sempre descrever exatamente a realidade social e política das nações, sob o perigo de tal documento torna-se apenas uma "folha de papel". Viu-se, ainda, em "A Força Normativa da Constituição", que para Hesse a Constituição deve ser um documento com força de lei, ideia cognominada de concepção concretista da Constituição. Por fim, viu-se com Haberle, em "Hermenêutica Constitucional: a sociedade aberta dos intérpretes da Constituição", que a Constituição de uma nação não deve ser interpretada apenas pelas autoridades, mas também por qualquer cidadão ou grupo social.

Ao unir-se sistematicamente os teoremas dos quatro renomados juristas (re)lidos, a hipótese não foi confirmada, pois torna-se clarividente que uma Constituição deveria servir para fundar uma nação e garantir direitos fundamentais a seu povo, de revés, todavia, a maioria das Constituições contemporâneas servem em maior relevo a poucos, notadamente os donos do capital/poder, os políticos e os empresários. Escorados na escusa da falta de recursos e na programaticidade da maioria das normas constitucionais, as autoridades negam-se a oferecer condições dignas de vida ao povo brasileiro.

Nessa direção, após todo o esposado, cumpre se perceber que as ideias de Sieyès, Lassalle, Hesse e Haberle se complementam e são de elevada relevância no entendimento e na compreensão sobre qual seja o papel de uma Constituição (para que ela serve) e a quem ele deve (ou deveria) servir. Resta óbvio que na maioria dos países do mundo as Constituições têm servido apenas para manter os privilégios dos donos do capital/poder em face dos mais pobres. Como lembra o jovem pesquisador Ronaldo Bastos, citando Atílio Baron e sua Filosofia política marxista, atualmente:

(...) mais da metade da humanidade tem que sobreviver com apenas um dólar por dia; o regime de servidão [notadamente em relações de trabalho] supera em muito o número de escravos na época da colonização da América; vive-se em um mundo de pobreza extrema, xenofobia, racismo e destruição 
TELES, Tayson Ribeiro. Para que serve e/ou a quem serve uma Constituição? Jusfilosofias à luz de Sieyès, Lassalle, Hesse e Haberle. Revista Eletrônica Direito e Política, Programa de Pós-Graduação Stricto Sensu em Ciência Jurídica da UNIVALI, Itajaí, v.13, n.1, 10 quadrimestre de 2018. Disponível em: www.univali.br/direitoepolitica - ISSN 1980-7791

das culturas; luta-se contra o tráfico internacional de crianças e órgãos, a exclusão social [os pobres não têm saúde educação, lazer etc.] e o crime organizado. ${ }^{55}$

E onde estão as Constituições que não ajudam ao mundo no combate a tais problemas? Suas letras de lei lindas e repletas de direitos belíssimos não têm aplicabilidade por quê? Por certo, são mesmo as Constituições textos com elevada carga utópica, mas que instam os Estados a promoverem o bem de todos, o desenvolvimento e a justiça sociais. Porém, esbarram nas volições dos políticos poderosos, os quais manobram textos de lei, orçamentos, fazem acordos, se vendem, matam-se, tudo por dinheiro e poder, ficando o povo secundarizado na estante de prioridades da Administração Pública - se é que está nesta estante.

No caso do Brasil, resta certo que nossas autoridades devem mudam seus pensamentos. Eliminar seus egoísmo, ganância e individualismo. Pensar mais nos pobres. Não em filantropia barata, mas sim em atitudes efetivas. Precisam entender que "as disposições constitucionais relativas à Justiça Social não são meras exortações ou conselhos, de simples valor moral"56, mas sim normas que "geram imediatamente direitos para os cidadãos [...] 'direitos subjetivos" ${ }^{\prime \prime 57}$. As Constituições são leis, foram feitas para serem cumpridas, para tirarem os povos do plasma de problemas em que se encontravam antes delas. É preciso que estas normas cumpram com seus papéis no teatro social.

\section{REFERÊNCIAS DAS FONTES CITADAS}

BASTOS, Ronaldo. O conceito do Direito em Marx. Porto Alegre: Fabris, 2012.

BAUMAN, Zygmunt. Modernidade líquida. Rio de Janeiro: Zahar, 2001.

GUTEMBERG, Luiz. Ulysses Guimarães. 2. ed. Brasília: Câmara dos Deputados, 2012, p. 408. Disponível em: <http://www2.camara.leg.br/documentos-e pesquisa/publicacoes/edicoes/paginas-individuais-dos-livros/ulyssesguimaraes>. Acesso em: 2 jun. 2017.

\footnotetext{
55 BASTOS, Ronaldo. 0 conceito do Direito em Marx. Porto Alegre: Fabris, 2012, p. 26.

56 MELLO, Celso Antônio Bandeira de. Eficácia das normas constitucionais e direitos sociais. São Paulo: Malheiros, 2015, p. 55.

57 MELLO, Celso Antônio Bandeira de. Eficácia das normas constitucionais e direitos sociais, p. 56.
} 
TELES, Tayson Ribeiro. Para que serve e/ou a quem serve uma Constituição? Jusfilosofias à luz de Sieyès, Lassalle, Hesse e Haberle. Revista Eletrônica Direito e Política, Programa de Pós-Graduaç̧ão Stricto Sensu em Ciência Jurídica da UNIVALI, Itajaí, v.13, n.1, $1^{\circ}$ quadrimestre de 2018. Disponível em: www.univali.br/direitoepolitica - ISSN 1980-7791

HABERLE, Peter. Hermenêutica Constitucional: a sociedade aberta dos intérpretes da Constituição. 2. ed. Tradução de Gilmar Ferreira Mendes. Porto Alegre: Fabris Editor, 2002.

HESSE, Konrad. A força normativa da Constituição. Tradução de Gilmar Ferreira Mendes. Porto Alegre: Fabris Editor, 1991.

LASSALLE, Ferdinand. A essência da Constituição. Tradução de João de Almeida. Rio de Janeiro: Lúmen Juris, 2009.

LYRA, Roberto Filho. O que é Direito. São Paulo: Brasiliense, 2012.

MELLO, Celso Antônio Bandeira de. Eficácia das normas constitucionais e direitos sociais. São Paulo: Malheiros, 2015.

PILATTI, Adriano. A Constituinte de 1987-1988: progressistas, conservadores, ordem econômica e regras do jogo. Rio de Janeiro: Lúmem Juris, 2008.

PINHO, Rodrigo César Rebello. Teoria geral da Constituição e direitos fundamentais. 11. ed. São Paulo: Editora Saraiva, 2011.

REALE, Miguel. Noções preliminares de Direito. 25. ed. São Paulo: Saraiva, 2001.

SIEYÈS, Joseph Emmanuel. A constituinte burguesa. Tradução de Norma Azevedo. 5. ed. Rio de Janeiro: Editora Lúmen Juris, 2009.

TELES, Tayson Ribeiro. Política de Cotas do Ensino Superior Brasileiro: Uma análise percuciente in faciem do Princípio Constitucional da Igualdade. Constituição, Economia e Desenvolvimento: Revista da Academia Brasileira de Direito Constitucional, Curitiba, v. 7, n. 12, pp. 233-255, jan-jun, 2015, pp. 237-238. Disponível em: <http://www.abdconst.com.br/revistas_interna13.php>. Acesso em: 2 jun. 2017.

Submetido em: 09/05/2017

Aprovado em: 28/06/2017 